УДК 343.131

DOI https://doi.org/10.32837/apdp.v0i83.121

О. М. Коріняк

\title{
РОЛЬ ПРОКУРАТУРИ УКРАЇНИ У ПРОЦЕСІ ЗАБЕЗПЕЧЕННЯ ГАРАНТІЙ НЕЗАЛЕЖНОСТІ СУДДІВ ТА АВТОРИТЕТУ ПРАВОСУДДЯ
}

Постановка проблеми. Конституційна реформа 2016 року зупинила наукові дискусії щодо статусу прокуратури України як окремої інституції у сфері правосуддя чи все ж таки однієї з ланок суддівської системи. Законом України «Про внесення змін до Конституції України (щодо правосуддя)» від 02.04.2016 року вирішено це питання шляхом внесення статті 131-1, що регулює засади діяльності прокуратури України, у розділ VIII «Правосуддя». Отже, будучи невід'ємною частиною системи правосуддя, керуючись такими засадами діяльності, як верховенство права, законність, незалежність, недопустимість незаконного втручання у діяльність судової влади, повага до незалежності суддів та в силу наданих законом повноважень, прокурори стають одними із суб'єктів правовідносин, які виникають при реалізації заходів, спрямованих на забезпечення гарантій незалежності суддів та авторитету правосуддя.

Оглядом положень законодавства легко прослідкувати процедурні зміни, які відбулися з цього питання. Так, нечинний на сьогодні Закон України «Про судоустрій та статус суддів» від 07.07.2010 року містив положення у статті 48 щодо обов'язку суддів звертатися з повідомленням про втручання в їхню діяльність як судді щодо здійснення правосуддя до органів суддівського самоврядування та правоохоронних органів [1]. Чинний Закон України «Про судоустрій та статус суддів» від 02.06.2016 року в аналогічній статті закріплює цей обов'язок судді з необхідністю звертатися до Вищої ради правосуддя та Генерального прокурора [2].

Неправильно думати, що до внесення змін до законодавства у цій частині прокурори залишалися осторонь процесу реагування на факти втручання у суддівську діяльність. Після внесення відомостей до Єдиного реєстру досудових розслідувань (далі - ЄРДР) про злочини, передбачені статтями 376 (втручання у суддівську діяльність), 377 (погроза або насильство щодо судді, народного засідателя чи присяжного), 378 (умисне знищення або пошкодження майна судді, народного засідателя чи присяжного), 379 (посягання на життя судді, народного засідателя чи присяжного у зв'язку з їхньою діяльністю, пов'язаною зі здійсненням правосуддя) Кримінального кодексу України, у кожному кримінальному провадженні відповідно до законодавчих положень присутній прокурор - процесуальний керівник. Проте, чи кожне повідомлення про факт злочинного втручання у суддівську діяльність, яке було адресовано безпосередньо органам Нацполіції, мало належне реагування, залишається під питанням.

Відповідно до зазначеного, у статті буде йтися про реагування прокурорами на факти незаконного втручання у діяльність суддів при здійсненні ними правосуддя, які мають ознаки кримінальних правопорушень. 
Аналіз останніх досліджень і публікацій. Обговорення питань суддівської незалежності та гарантій її забезпечення є досить популярним та жвавим у наукових кругах. Зокрема, правові позиції з цього приводу містяться у працях вчених В.Д. Бринцева, Т.В. Галайденко, В.В. Городовенка, С.В. Ківалова, І.Є. Марочкіна, Є.В. Єршова, І.Л. Петрухіна та інших. Динамічні процеси реформування судової системи, циклічність яких не в останню чергу залежить від політичних змін у державі, змушують постійно аналізувати стан та якість роботи суб'єктів відповідної сфери правовідносин. Враховуючи те, що безпосереднє визначення у суддівському законі Генерального прокурора як суб'єкта реагування на факти зазіхання на незалежність представників Феміди відбулося кілька років тому, вже можна надати першу оцінку результативності запроваджених новел та їх слабких місць.

Метою статті є висвітлення практичного аспекту реалізації окремих законодавчих положень щодо недопущення втручання у суддівську діяльність під час здійснення правосуддя, дослідження у цьому процесі ролі органів прокуратури України як суб’єкта правовідносин, визначення проблемних питань та пропозиція шляхів їх вирішення.

Під час дослідження цього питання було опрацьовано інформацію, яка міститься як у відкритих, так і в закритих електронних базах даних, зокрема, Реєстрі повідомлень суддів про втручання в діяльність та відповідні акти Вищої ради правосуддя (далі - ВРП), Єдиному державному реєстрі судових рішень, ЄРДР, системі електронного документообігу органів прокуратури України, а також інформацію з відкритих джерел, насамперед офіційних статистичних звітів відповідних органів, електронні публікації за темою дослідження в мережі Інтернет тощо. Крім того, було вивчено практику розгляду у 2019 році органами прокуратури повідомлень суддів про втручання в їх діяльність щодо здійснення правосуддя; з' ясовано стан розгляду подань ВРП, внесених Генеральному прокурору, про притягнення до встановленої законом відповідальності осіб, які допустили порушення; опрацьовано судові рішення відповідної категорії та стан досудового розслідування кримінальних проваджень про злочини у сфері правосуддя.

Виклад основного матеріалу дослідження. Встановлено, що за 9 місяців 2019 року до Генеральної прокуратури України надійшло 153 повідомлення суддів про втручання у їх діяльність. Переважно вони стосувалися висвітлення неправдивої, на думку суддів, інформації у засобах масової інформації та мережі Інтернет, заявлення їм відводів або подання сторонами процесу до уповноваженого органу дисциплінарних скарг на їхні дії.

За результатами розгляду таких повідомлень ВРП приймаються рішення про відсутність підстав для вжиття заходів щодо забезпечення незалежності суддів та авторитету правосуддя, визначених у ст. 73 Закону України «Про Вищу раду правосуддя». Зокрема, факт використання сторонами своїх процесуальних прав, наданих законодавством, може свідчити лише про зловживання ними, однак не є доказом спроби тиску чи впливу на суддів. Факти поширення недостовірної інформації у засобах масової інформації слід оцінювати через призму положень статті 10 Конвенції про захист прав людини і основоположних свобод, рішення Європейського суду з прав людини у справі «Українська прес-група проти України» 
від 29.03.2005 та Висновок Консультативної ради європейських суддів № 18 (2015) «Позиція судової влади та її відносини з іншими гілками державної влади в умовах сучасної демократії, які зводяться до гарантій права кожного на свободу вираження поглядів, критики, озвучення певних припущень, а також статусу суддів як публічних осіб, яким не слід бути занадто чутливими.

Саме така позиція членів ВРП передувала винесенню відмовних рішень про відсутність підстав для вжиття заходів, передбачених ст. 73 Закону, за повідомленнями суддів: рішення ВРП від 04.06.2019 № 1535/0/15-19, від 18.06.2019 № 1656/0/15-19, від 13.06.2019 № 1630/0/15-19, від 20.06.2019 № 1688/0/1519, від 11.04.2019 № 1130/0/15-19, від 26.03.2019 № 953/0/15-19, від 25.07.2019 № 1953/0/15-19, від 01.08.2019 № 2291/0/15-19, від 20.08.2019 № 2224/0/15-19 та інших [3].

При цьому в органах прокуратури відсутній єдиний підхід щодо реагування на повідомлення суддів подібного змісту. Так, мають місце випадки як внесення відомостей до ЄРДР, так і відмови в їх реєстрації. Наприклад, за результатами розгляду повідомлення судді Білоцерківського міськрайонного суду Київської області О.П. Шовкопляса щодо можливого втручання в його діяльність шляхом висловлення учасником провадження бажання звернутися до ВРП із дисциплінарною скаргою на дії цього судді прокуратурою області прийнято обгрунтоване рішення про відсутність підстав для внесення відомостей до ЄРДР за ст. 376 КК України. В ході розгляду вказаного повідомлення було опитано учасника провадження, який підтвердив висловлені головуючому судді слова щодо наміру реалізувати свої процесуальні права шляхом звернення із дисциплінарною скаргою. Інших дій, у тому числі здійснення психологічного чи фізичного тиску, він стосовно судді не вчиняв. Відтак судді надано відповідь у порядку Закону України «Про звернення громадян» .

По-іншому було вирішено органами прокуратури повідомлення судді Бориспільського міськрайсуду Є.О. Борця щодо тиску на нього шляхом подачі численних скарг голові суду, до ВРП та Вищої кваліфікаційної комісії суддів України. За цим фактом розпочато досудове розслідування у кримінальному провадженні за ч. 1 ст. 376 КК України. Натомість рішенням ВРП від 21.02.2019 № 534/0/15-19 при перевірці цього повідомлення відмовлено у вжитті заходів щодо забезпечення незалежності суддів та авторитету правосуддя, оскільки правова оцінка цьому факту вже буде надана під час розслідування відповідного кримінального провадження [3].

Різне праворозуміння та правозастосування при встановленні ознак складу злочину, передбаченого ст. 376 КК України, пов’язано передусім із відсутністю законодавчого визначення у кримінально-правовому полі дефініції «втручання в діяльність судді» .

Кримінальний кодекс України у статті 376 «Втручання в діяльність судових органів» визначає як вплив у будь-якій формі на суддю з метою перешкодити виконанню ним своїх службових обов'язків або добитися винесення неправосудного рішення [4]. При цьому у науково-практичних коментарях до цієї статті об'єктивна сторона характеризується як вплив у будь-якій формі на суддю з метою перешкодити виконанню ним своїх службових обов'язків або добитися винесення неправосудного рішення. До конкретних форм впливу віднесено прохання, вка- 
зівку, погрозу, підкуп, критику судді в засобах масової інформації до вирішення конкретної справи у зв’язку з її розглядом, проведення пікетів, мітингів тощо [5].

Постанова Пленуму Верховного Суду України від 13.06.2007 № 8 «Про незалежність судової влади», окрім форм впливу, перелічених вище, також зазначає вимогу та насильство. Метою є схиляння судді до вчинення чи невчинення певних процесуальних дій або ухвалення певного судового рішення. При цьому не має значення, за допомогою яких засобів, на якій стадії процесу та в діяльність суду якої інстанції здійснюється втручання [6].

Водночас у щорічній доповіді «Про стан забезпечення незалежності суддів в Україні за 2018 рік» ВРП дійшла висновку, що, оскільки у багатьох випадках повідомлювані суддями факти перебувають на межі різних правових понять, їх юридична оцінка не може бути однозначною [7]. Така термінологічна невизначеність не сприяє процесу правильної юридичної оцінки факту втручання в діяльність судових органів. Визначений у ч. 4 ст. 48 Закону України «Про судоустрій і статус суддів» обов' язок судді повідомляти про всі випадки втручання в його діяльність щодо здійснення правосуддя (факт неповідомлення може бути підставою для притягнення до дисциплінарної відповідальності, стаття 106 вказаного Закону), а також відсутність чіткого розуміння того, які саме діяння слід вважати втручанням у здійснення правосуддя, нерідко призводить до безпідставного відволікання органів досудового розслідування.

Для прикладу, у Луганській області розслідувалося провадження за ч. 1 ст. 376 КК України за повідомленням судді Лисичанського міського суду про виявлення нею на робочому столі відбитка взуття. Під час здійснення досудового розслідування було проведено низку слідчих дій, у тому числі судові трасологічну та дактилоскопічну експертизи. Надалі прийнято рішення про закриття кримінального провадження.

Відсутність юридичної конкретики з цього питання має наслідком щорічне збільшення кількості розпочатих кримінальних проваджень за ст. 376 КК України без подальшої судової їх перспективи. Так, відповідно до статистичних відомостей, протягом 2018-2019 років за ст. 376 КК України розпочато 414 кримінальних проваджень (у тому числі 67 на виконання ухвал слідчих суддів), із яких кожне четверте було закрито у зв'язку з відсутністю складу злочину, і лише два обвинувальних акти було направлено до суду [8]. Подібний стан справ спостерігався і в попередні роки: у 2017 році - чотири обвинувальні акти направлено до суду, у 2016 - два.

Це пояснює дефіцит обвинувальних вироків за статтею 376 КК України. Опрацюванням відомостей, що містяться в Єдиному державному реєстрі судових рішень, встановлено лише три обвинувальних вироки у двох кримінальних справах заст. 376 КК України: 2 - суду першої інстанції (віо 19.06.2012 справа № 1006/3678/12;

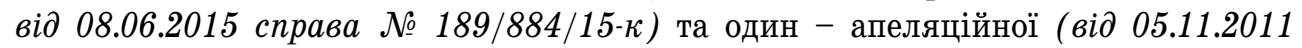
справа № 189/884/15-к) [9]. Аналіз цих рішень засвідчив, що втручання в діяльність суддів в обох випадках мало місце шляхом особистого висловлення обвинуваченими неконкретизованих погроз із метою домогтися винесення неправосудного рішення та перешкодити виконанню суддями своїх службових обов'язків. 
Можна підсумувати, що без чіткого законодавчого визначення самого змісту втручання у суддівську діяльність, яке має наслідком притягнення до кримінальної відповідальності, збільшення кількості безперспективних кримінальних проваджень буде продовжуватися. I це притому, що органи прокуратури при вирішенні питання у порядку ст. 214 КПК України щодо реєстрації відомостей за ст. 376 КК України виважено підходять до кожного повідомлення суддів, працюючи так би мовити певним запобіжником від внесення до ЄРДР відомостей, які мають вирішуватися у порядку законодавства про розгляд звернень громадян.

В окремих випадках саме за такі дії органи прокуратури стають об’єктом критики ВРП і змістом рішень, у яких рада ініціює питання про притягнення до відповідальності осіб, які допустили порушення закону. Йдеться про досить пограничні ситуації, викладені у повідомленнях суддів про втручання у їх діяльність, де зі змісту не вбачаються обставини, які можуть свідчити про вчинення будь-якого кримінального правопорушення.

З цього приводу позиція ВРП щодо обов' язковості внесення відомостей до ЄРДР узгоджується з позицією Вищого спеціалізованого суду України з розгляду цивільних і кримінальних справ, викладеною у листі від 12.01.2017 № 9-49/0/4-17, яка полягає у тому, що якщо особа порушує перед органом досудового розслідування питання про вчинення кримінального правопорушення, ініціюючи здійснення дій, визначених КПК України, то навіть за умови, що результати аналізу наведених відомостей свідчать про відсутність ознак складу злочину, такі відомості мають бути внесені до ЄРДР із подальшим закриттям кримінального провадження відповідно до ст. 284 КПК України. Така позиція викладена у рішеннях від 12.01.2019 № 449/0/15-19, від 05.02.2019 № 334/0/15-19, від 18.04.2019 № 1192/0/15-19 та інших [3].

Лише поточного року Генеральному прокурору було внесено низку подань на підставі статті 74 Закону України «Про Вищу раду правосуддя» саме за порушення, на думку ВРП, вимог ст. 214 КПК України. Не погоджуючись із такою позицію судових органів, окрім чіткого визначення у статті 214 КПК обов'язку реєструвати відомості в ЄРДР лише за наявності обставин, які можуть свідчити про наявність кримінального правопорушення, варто привести в захист позиції органів прокуратури й аргумент завантаженості прокурорів - процесуальних керівників. Щорічно по Україні реєструється понад мільйон кримінальних правопорушень, з урахуванням залишку попередніх років на рік доводиться розслідувати від 1,7 до 2 мільйонів кримінальних проваджень, навантаження на одного прокурора у таких великих містах, як Київ, Харків, Одеса по 400-600 проваджень. Отже, бездумна реєстрація в ЄРДР усіх повідомлень про втручання у суддівську діяльність не сприятиме покращанню стану захисту гарантій незалежності суддів, а лише призведе до штучного збільшення статистики за відсутності такого очікуваного результату, як направлення обвинувального акта до суду за фактом вчинення злочину проти правосуддя.

Висновки. 3 метою налагодження якісної співпраці між Вищою радою правосуддя і Генеральною прокуратурою України та покращання нагляду за досудовим розслідування злочинів вказаної категорії, останньою вжито низку заходів організаційного та процесуального характеру, серед яких, окрім іншого, є здійснення 
з боку керівництва відомства контролю за станом досудового розслідування кримінальних проваджень про злочини у сфері правосуддя та включення до складу групи процесуальних прокурорів у конкретних кримінальних провадженнях найбільш досвідчених працівників, у тому числі, які обіймають керівні посади в органах прокуратури.

Водночас лише узгодженням правових позицій та виробленням уніфікованої практики розгляду ВРП та Генеральною прокуратурою України повідомлень про втручання у діяльність суддів, а також визначенням у нормативно-правових документах змісту такого втручання та його наслідків у кримінально-правовій площині правовідносин можна буде звітувати не про формальне виконання положень законодавства, апродієвістьцієїроботи, якапосилилазахистпредставників Феміди.

\section{Jimepamypa}

1. Закон України «Про судоустрій та статус суддів» від 7 липня 2010 року № 2453-VI; зі змін. і доповн. [Електронний ресурс]. - Режим доступу: https://zakon.rada.gov.ua/laws/show/245317?find= 1\&text=\% E2\% F2\% F0\% F3\% F7\% E0\% ED\#w13.

2. Закон України «Про судоустрій та статус суддів» від 2 червня 2016 року № 1402-VIII; зі змін. і доповн. [Електронний ресурс]. - Режим доступу: https://zakon.rada.gov.ua/laws/show/140219?find= 1\&text= $\%$ E2 $\%$ F2 $\%$ F0\% F3\% F7\% E0\% ED\#w14.

3. Реєстр повідомлень суддів про втручання в діяльність. [Електронний ресурс]. - Режим доступу: http://hcj.gov.ua/intervention.

4. Кримінальний кодекс України від 5 квітня 2001 року № 2341-III; зі змін. і доповн. [Електронний ресурс]. - Режим доступу: https://zakon5.rada.gov.ua/laws/show/2341-14.

5. Коментар до Кримінального кодексу України. [Електронний ресурс]. - Режим доступу: http://yurist-online.com/ukr/uslugi/yuristam/kodeks/024/373.php.

6. Постанова Пленуму Верховного Суду України від 13.06.2007 № 8. [Електронний ресурс]. - Режим доступу: «Про незалежність судової влади» https://zakon.rada.gov.ua/laws/show/v0008700-07.

7. Щорічна доповідь Вищої ради правосуддя «Про стан забезпечення незалежності суддів в Україні за 2018 рік». [Електронний ресурс]. - Режим доступу: http://hcj.gov.ua/sites/default/files/field/ file/shchorichna_dopovid_za_2018_rik.pdf.

8. Єдиний звіт про кримінальні правопорушення. Форма № 1 (за січень-грудень 2018 року, січень-вересень 2019 року. [Електронний ресурс]. - Режим доступу: https://www.gp.gov.ua/ua/ stst2011.html?dir_id $=113653 \&$ libid $=100820 \& \mathrm{c}=$ edit\&_c $=$ fo.

9. Єдиний державний реєстр судових рішень. [Електронний ресурс]. - Режим доступу: http://reyestr.court.gov.ua/.

\section{Анотація}

Коріняк О. М. Роль прокуратури України у процесі забезпечення гарантій незалежності суддів та авторитету правосуддя. - Стаття.

Стаття присвячена питанню стану додержання вимог законодавства щодо забезпечення гарантій незалежності суддів через призму реагування органами прокуратури на факти втручання у суддівську діяльність, які містять склад злочину, передбаченого статтею 376 Кримінального кодексу України. При написанні статті взято за основу відповідні статистичні показники органів досудового розслідування та органів прокуратури, досліджені результати досудового розслідування конкретних прикладів кримінальних проваджень, вивчена практика розгляду відповідних заяв про втручання у суддівську діяльність Вищою радою правосуддя та органами прокуратури України.

Наукова цінність вказаної статті полягає в тому, що тї зміст та отримані висновки відображають реальний стан справ виконання покладених обов'язків уповноваженими суб'єктами із заданої тематики. Висвітлені практичні проблеми організації вказаної роботи та запропоновані шляхи для покращання діяльності двох інституцій (Генеральної прокуратури України та Вищої ради правосуддя), спрямованої на забезпечення додержання гарантій незалежності суддівського корпусу.

За результатами цього наукового дослідження сформовані висновки щодо необхідності більш чіткого законодавчого визначення словосполучення «втручання у суддівську діяльність», яке має наслід- 
ком настання кримінальної відповідальності, та зміни підходів суб'єктів реагування на факти відповідних повідомлень суддів. Уніфікація підходів до правотлумачення та правозастосування положень законодавства із визначеного питання представниками судової гілки влади та правоохоронних органів сприятиме посиленню гарантій незалежності суддів та авторитету правосуддя в Україні.

Ключові слова: втручання у суддівську діяльність, вплив на суддю, незалежність суддів, прокурорське реагування на факти втручання у суддівську діяльність, стаття 376 (втручання в діяльність судових органів) Кримінального кодексу України, реєстрація відомостей до Єдиного реєстру досудових розслідувань, практика прокурорів із розгляду повідомлень про кримінальні правопорушення, практика Вищої ради правосуддя.

\section{Summary}

Korinyak $O$. M. Role of the public prosecution service of Ukraine in ensuring the independence of judges and the power of justice. - Article.

The article focuses on the state of compliance with the requirements of the legislation on ensuring the guarantees of the independence of judges from the perspective of the prosecution bodies' response to the facts of interference with judicial activity, which constitutes the crime provided for by Article 376 of the Criminal Code of Ukraine. The relevant statistics of pre-trial investigation and prosecution bodies, the results of pre-trial investigation of specific criminal proceedings, the practice of considering relevant applications on the interference of the High Council of Justice and the prosecution bodies of Ukraine with judicial activity provided the basis when writing this article.

The scientific value of this article consists in the fact that its contents and the findings reflect the reality of the authorized subjects' fulfilment of the assigned duties on a given subject. Practical problems of the organization of the aforementioned activity are highlighted and the ways to improve the activity of two institutions (the Prosecutor General's Office of Ukraine and the High Council of Justice), which is aimed at ensuring the guarantees of the independence of the judiciary, are proposed in this article.

Based on the findings of this research, conclusions were drawn as to the need for a clearer legislative definition of the phrase 'interference with judicial activity', which results in criminal liability, as well as the need for changes in the subjects' response to the facts of the relevant communications of judges. The harmonization of approaches to interpretation and application of the provisions of law on a particular issue by the representatives of the judicial branch and law enforcement agencies will strengthen the guarantees of the independence of judges and the power of justice in Ukraine.

Key words: interference with judicial activity, influence on a judge, independence of judges, prosecutor's response to the facts of interference with judicial activity, Article 376 (interference with the activity of judicial authorities) of the Criminal Code of Ukraine, registration of information with the Unified Register of Pre-Trial Investigations, prosecutor's practice concerning consideration of reports of criminal offences, practice of the High Council of Justice. 